RESEARCH ARTICLE

\title{
Determining the presence of cyanotoxins in water reservoirs of Anuradhapura, using molecular and bioassay methods
}

\author{
D.N. Magana Arachchi* and H.M. Liyanage \\ Institute of Fundamental Studies, Hantana Road, Kandy.
}

Revised: 20 March 2012 ; Accepted: 03 May 2012

\begin{abstract}
This study was performed to detect the presence of cyanotoxin producing organisms in the reservoirs of the Anuradhapura Distrct. Water samples were collected from Kala wewa, Tissa wewa and Nuwara wewa in Anuradhapura. Environmental and cultured samples were subjected to PCR to detect cyanobacteria, Microcystis, microcystin, Cylindrospermopsis and cylindrospermopsin, targeting the specific $16 \mathrm{~S}$ rRNA and cpc, mcyA and $m c y E$, cylindrospermopsin synthetase ( $r p o C 1)$ and cylindrospermopsin specific peptide synthase (PS) genes, respectively. All tested samples were positive for unicellular and five were positive for filamentous cyanobacteria. In all three reservoirs, positive amplification was observed for $m c y \mathrm{~A} /$ $m c y E$ genes indicating the presence of cyanobacterial strains with genetic potential to produce microcystins. A positive amplification resulted in samples cultured from Nuwara wewa for rpoCl gene confirming the presence of Cylindrospermopsis species in the reservoir. Further more, an environmental sample from Nuwara wewa was positive for PS gene confirming the presence of toxic Cylindrospermopsis species, and thereby cylindrospermopsin in that reservoir. Bioassay was performed using Artemia salina to test the toxicity of water samples. Filtrates and filters were assayed and in all three tanks, higher toxicities were recorded for filters of both environmental and cultured samples. Among filters, the highest toxicity was recorded in two environmental samples from Nuwara wewa with a mean $\mathrm{LD}_{50}$ value of $-694 \mathrm{ppm}$. Among cultured samples, the highest toxicity of -1128.28 ppm was recorded from Kala wewa. According to molecular and bioassay findings, all three lakes have a wide distribution of cyanobacterial species with toxin generating ability and it might be a potential risk factor for the health issues that prevail in the Anuradhapura District.
\end{abstract}

Keywords: Bioassays, cyanotoxins, Cylindrospermopsis, Microcystis, PCR.

\section{INTRODUCTION}

Most chemical contaminants in drinking water become health concerns only after exposure for long periods. A number of chemical contaminants in drinking water, have been shown to cause adverse health effects in humans after prolonged exposure.

Cyanotoxins are well recognized as cause for a number of livestock and human poisonings (Sivonen et al., 1990; Kuiper-Goodman et al., 1999). There are several toxic cyanobacteria found in inland and coastal waters and at least 46 species have been shown to cause toxic effects in vertebrates (Sivonen \& Jones 1999). The most common cyanobacteria in fresh water are colonial Microcystis spp. and filamentous Cylindrospermopsis raciborski, Planktothrix (syn. Oscillatoria) rubescens, Planktothrix (syn. Oscillatoria) agardhii, Gloeotrichia spp., Anabaena spp., Nostoc spp., Lyngbya spp., Aphanizomenon spp., Synechococcus spp., some Oscillatoria spp., Schizothrix spp., Anabaenopsis spp., and Hapalosiphon spp., (Sivonen \& Jones, 1999). Among potentially toxic cyanobacterial species, several chemically and toxicologically diverse compounds have been isolated, purified and characterized (Lawton et al., 1994; Sivonen \& Jones, 1999).

Health impairments are shown in numerous anecdotal reports of irritations of the skin and/or mucous membranes and in documented cases of illness after exposure through drinking water as well as accidental swallowing or aspiration of scum material (Chorus et al., 2000). 
Among the cyanotoxins, microcystins are the predominant toxins in freshwater lakes worldwide, which have been implicated in several cases of animal and human intoxications (Kuiper-Goodman et al., 1999). Progressive active liver injury (Falconer et al., 1983) and the potential for promotion of tumour growth are two aspects of microcystin damage. Anumber of human deaths have been reported resulting from exposure to the cyanobacterial toxin, microcystin and both cylindrospermopsin and microcystin have been detected in drinking water (Byth, 1980; Falconer et al., 1983; Hawkins et al., 1985; Falconer, 2005). Cylindrospermopsin is a general cytotoxin that blocks protein synthesis (Falconer, 1996), and the first clinical symptoms of cylindrospermopsin are kidney and liver failure. In contrast to the pure toxin, crude extracts of the organism also cause injury to the lungs, adrenals and intestine. This indicates that other toxins may also be present in the organism. Since clinical symptoms may become manifest only several days after exposure, it will often be difficult to determine a cause-effect relationship. Patients intoxicated with cylindrospermopsin via drinking water in an incident in Australia, escaped death only through skilled and intensive hospital care (Falconer, 2005).

Cyanobacteria are the dominant microbial inhabitants of rice fields. Anabaena spp., Cylindrospermum spp., Hapalosiphon spp., Lyngbya spp., Nostoc spp., Phormidium spp., Oscillatoria spp., Aulosira spp., Rivularia spp., Gloeotrichia spp., Tolypothrix spp., Fischerella spp., Aphanothece spp., Gloeothece spp., and some unidentified cyanobacteria were also recorded in paddy fields (Roger \& Kulasooriya, 1980). Most of these genera have toxin generating ability and therefore, there is a high probability that these cyanotoxins can contaminate rice.

This research study was aimed at identifying the cyanotoxins present in certain water bodies of the Anuradhapura District.

\section{METHODS AND MATERIALS}

Site selection and sample collection: Kala wewa, Tissa wewa and Nuwara wewa in the District of Anuradhapura were selected for water sample collection in June 2010 (Table 1). All samples were collected in sterile brown glass containers. The samples were collected from the water surface and the water column $(\sim 0.1-15 \mathrm{~m})$, to represent the whole water body (three replicates were collected from each site). The temperature and $\mathrm{pH}$ were recorded using a thermometer and a $\mathrm{pH}$ meter, respectively. Morphological observations were also made of each sample, using a compound light microscope (Olympus $\mathrm{BH}-2)(400-1,000 \times)$ and standard morphological study methods.

Culturing of water samples: Collected water samples were concentrated by centrifugation (3500 rpm, $10 \mathrm{~min}$ ) and $500 \mu \mathrm{L}$ of the resulting pellet and $500 \mu \mathrm{L}$ from the supernatant were inoculated into cyano specific BG11, $\mathrm{BG} 11_{0}, \mathrm{BG} 11_{0} \mathrm{C}$ and MLA media. The cultures were incubated at room temperature with 12 - 12 light dark cycling. Morphological observations were made of each sample, using compound light microscope (Olympus

Table 1: Environmental and cultured samples selected for molecular detection

\begin{tabular}{|c|c|c|c|c|c|c|}
\hline No & $\begin{array}{l}\text { Sample } \\
\text { code }\end{array}$ & Collected place & $\begin{array}{l}\text { Environmental/ } \\
\text { cultured }\end{array}$ & Water body & $\begin{array}{c}\text { Temperature } \\
{ }^{0} \mathrm{C}\end{array}$ & $\mathrm{pH}$ \\
\hline 1 & AN 6 & Nuwara wewa & Environmental & Bottom $-1.5 \mathrm{~m}$ & 28 & 8.60 \\
\hline 2 & AN 7 & Nuwara wewa & Environmental & Bottom - $11 \mathrm{~m}$ & 28 & 8.43 \\
\hline 3 & AN8 & Nuwara wewa & Environmental & Surface- Plankton net & 28 & 8.50 \\
\hline 4 & AT 5 & Tissa wewa & Environmental & Surface & 28 & 8.34 \\
\hline 5 & AT6 & Tissa wewa & Environmental & Surface- Plankton net & 28 & 8.35 \\
\hline 6 & AK 1 & Kala wewa & Environmental & Bottom - $15 \mathrm{~m}$ & 27 & 8.48 \\
\hline 7 & AK 3 & Kala wewa & Environmental & Surface & 27 & 8.93 \\
\hline 8 & AK1-C & Kala wewa & Cultured-MLA & - & - & - \\
\hline 9 & AK3-C & Kala wewa & Cultured-MLA & - & - & - \\
\hline 10 & AT5-C & Tissa wewa & Cultured-MLA & - & - & - \\
\hline 11 & AT6-C & Tissa wewa & Cultured-MLA & - & - & - \\
\hline 12 & AN6-C & Nuwara wewa & Cultured-MLA & - & - & - \\
\hline 13 & AN7-C & Nuwara wewa & Cultured-MLA & - & - & - \\
\hline
\end{tabular}


BH-2) $(400-1,000 \times)$ by standard morphological methods.

\section{Molecular detection:}

a) DNA extraction and purification: Five hundred microlitres of both environmental and cultured water samples from each site (Table 1) along with $500 \mu \mathrm{L}$ of standard Microcystis aeruginosa culture [obtained from the Pasteur Culture Collection (PCC 7941), France] were subjected to DNA extraction. Each sample was transferred to $500 \mu \mathrm{L}$ of $1 \mathrm{x}$ Tris EDTA (TE) buffer and subjected to sequential heating (at $99{ }^{\circ} \mathrm{C}$ for $5 \mathrm{~min}$ ) and freezing (at $-5^{\circ} \mathrm{C}$ for $5 \mathrm{~min}$ ) three times, to achieve lysis. The samples were centrifuged $(12,000 \mathrm{rpm}, 5 \mathrm{~min})$ and to each resulting pellet, $40 \mu \mathrm{L}$ of $\mathrm{N}$-Tris (Hydroxymethyl) methyl-2-amino-ethanesulfonic acid (TES) and $20 \mu \mathrm{L}$ of lysozyme $(10 \mathrm{mg} / \mathrm{mL})$ were added, and incubated overnight at $37^{\circ} \mathrm{C}$. The cells were then treated with $10 \mu \mathrm{L}$ of proteinase $\mathrm{K}(20 \mathrm{mg} / \mathrm{mL})$ and $40 \mu \mathrm{L}$ of TE/ Sodium dodecyl sulfate (SDS) and incubated at $55{ }^{\circ} \mathrm{C}$ for $2 \mathrm{~h}$ to lyse the organisms further. Subsequently, proteinase $\mathrm{K}$ was inactivated by heating the sample at $95{ }^{\circ} \mathrm{C}$ for 10 min. Nucleic acids were purified by Boom's method (Boom et al., 1990), using silica particles and guanidium isothiocyanate.

b) Detection of cyanobacteria, Cylindrospermopsis, Microcystis, microcystin and cylindrospermopsin generating genes using Polymerase Chain Reaction (PCR) amplification: DNA amplification was performed for the $16 \mathrm{~S}$ rRNA gene and phycocyanin operon, which includes the genes responsible for coding of two phycobiliprotein subunits $(c p c \mathrm{~B}$ and $c p c \mathrm{~A})$ and three linker polypeptides, to identify the presence of cyanobacteria using the modified protocols of Nübel et al. (1997) and Premanandh et al. (2006), respectively. Cyanobacterial specific primers, forward primer CYA 359F (5'-GGGGAATCTTCCGCAATGGG-3') along with the reverse primers CYA781Rb (5'-GACTACA GGGGTATCTAATCCCTTT-3') and CYA781Ra (5'GACTACT GGGGTATCTAATCCCATT-3') and an equimolar mixture of reverse primers CYA781 Ra + CYA $781 \mathrm{Rb}$ were used for $16 \mathrm{~S}$ rRNA gene identification. Phycocyanin gene specific primers, forward primer cpc_arF (5'-TCGAAGATCGTTGCTTGAACG-3') and cpc_arR (5'-TTAGGTCCCTGC ATTTGGGTG-3') were used for $c p c$ gene identification. The total $25 \mu \mathrm{L}$ of reaction mixture contained $3 \mu \mathrm{L}$ of $5 \mu \mathrm{M}$ each primer, $2.5 \mu \mathrm{L}$ of $1 \mu \mathrm{M}$ each deoxynucleoside triphosphate, $5 \mu \mathrm{L}$ of $5 \mathrm{x}$ PCR buffer, $2 \mu \mathrm{L}$ of $25 \mathrm{mM} \mathrm{MgCl}_{2}, 1.25 \mathrm{U}$ of Taq DNA polymerase (Promega, Wisconsin, USA) and $5 \mu \mathrm{L}$ of template DNA.
In order to detect the microcystin synthetase (mcy) gene cluster for the identification of toxic Microcystis strains in the water source, DNA amplification was performed for $m c y \mathrm{E}$ and $m c y \mathrm{~A}$ genes using the general microcystin synthetase gene $\mathrm{E}$ forward primer mcyE-F2 (5'-GAAATTTGTGTAGAAGGTGC-3') and the genusspecific reverse primer for Microcystis MicmcyE-R8 (5'-CAATGGGAGCATAACGAG-3') (Vaitomaa et al., 2003) and primers, which code for Microcystis specific microcystin synthetase gene A forward primer McyAR47 (5' - CTCCCTCTAAAACCCGCAGTAAG- 3'), and the gene specific reverse primer for Microcystis McyAF19 (5' - AACATCCAGCAGTTGAGCAAGC- 3') (primers were self designed using Primer3 software) along with the other ingredients as mentioned above.

Detection of Cylindrospermopsis raciborskii was carried out according to the protocol of Kim et al. (2000), using rpoC1 - 1 forward primer (3'-GAGCTCCAAAAC CATCCACTCAGG-5') and rpoC1-T reverse primer (5' GGTACCAAACGGACAAATAGTTGG-3') (Palenik \& Haselkorn, 1992), which codes for C. raciborskii specific cylindrospermopsin synthetase gene. Further, for the detection of cylindrospermopsin, forward primer M13 (5' GGCAAATTGTGATAGCCACGAGC-3') and reverse primer M14 (5'-GATGGAACATCGCTCACTGGTG -3'), which codes for cylindrospermopsin specific peptide synthase (PS) gene were used according to the protocol of Schembri et al. (2001), along with the other ingredients as mentioned above.

All the amplifications were carried out in Techne TC 3000 DNA Thermal Cycler. A single cycle of initial denaturation for $5 \mathrm{~min}$ at $94{ }^{\circ} \mathrm{C}$ followed by 35 incubation cycles each consisting of $1 \mathrm{~min}$ at $94{ }^{\circ} \mathrm{C}$, $1 \mathrm{~min}$ at $60{ }^{\circ} \mathrm{C}, 56{ }^{\circ} \mathrm{C}$ and $59{ }^{\circ} \mathrm{C}$ for $16 \mathrm{~S}$ rRNA gene, $c p c$ gene, $m c y \mathrm{~A}$ gene and $m c y \mathrm{E}$ gene, respectively and $1 \mathrm{~min}$ at $72{ }^{\circ} \mathrm{C}$ followed by $15 \mathrm{~min}$ extension at $72{ }^{\circ} \mathrm{C}$. A touchdown PCR was carried out with a single cycle of initial denaturation for $5 \mathrm{~min}$ at $94{ }^{\circ} \mathrm{C}$ followed by 5 incubation cycles each consisting of $1 \mathrm{~min}$ at $94{ }^{\circ} \mathrm{C}, 1 \mathrm{~min}$ at $62{ }^{\circ} \mathrm{C}$ and $1 \mathrm{~min}$ at $72{ }^{\circ} \mathrm{C}$ and another 5 cycles at $60{ }^{\circ} \mathrm{C}$ and 30 cycles at $58{ }^{\circ} \mathrm{C}$ followed by $15 \mathrm{~min}$ extension at $72{ }^{\circ} \mathrm{C}$ for the amplification of cylindrospermopsin specific peptide synthase (PS) gene. Further, another touchdown PCR was carried out as above, with 5 cycles at $61{ }^{\circ} \mathrm{C}, 5$ cycles at $58{ }^{\circ} \mathrm{C}$ and 30 cycles at $56^{\circ} \mathrm{C}$ for the amplification of cylindrospermopsin synthetase gene. Aliquots of the resulted amplified products were electrophoresed in $1.5 \%$ agarose gels containing $10 \mu \mathrm{g} / \mathrm{mL}$ ethidium bromide and documented through a gel documentation system (Syngene, UK). 


\section{Bioassay detection:}

a) Extraction of toxins: In order to detect the dissolved, intracellular and total cyanotoxins in water, environmental and cultured samples (Table 2) were filtered using Whatman's membrane filter papers. Each membrane with the residue was processed according to the protocol described by Fastner et al. (1998), vacuum dried at $45{ }^{\circ} \mathrm{C}$ and the toxin was extracted into $100 \%$ methanol. Each filter and filtrate was then subjected to the bioassay.

Table 2: Environmental and cultured samples selected for bioassay detection

\begin{tabular}{|c|c|c|c|}
\hline No. & Sample code & Collected place & $\begin{array}{l}\text { Environmental/ } \\
\text { cultured }\end{array}$ \\
\hline 1 & AN 1 & Nuwara wewa & Environmental \\
\hline 2 & AN 6 & Nuwara wewa & Environmental \\
\hline 3 & AN 7 & Nuwara wewa & Environmental \\
\hline 4 & AT 5 & Tissa wewa & Environmental \\
\hline 5 & AK 1 & Kala wewa & Environmental \\
\hline 6 & AK 3 & Kala wewa & Environmental \\
\hline 7 & AN 1 & Nuwara wewa & BG11 and $\mathrm{BG} 11_{0} \mathrm{C}$ \\
\hline 8 & AN 6 & Nuwara wewa & BG11 \\
\hline 9 & AN 7 & Nuwara wewa & BG11 0 C and MLA \\
\hline 10 & AT 5 & Tissa wewa & BG11 \\
\hline 11 & AT 3 & Tissa wewa & BG11 \\
\hline 12 & AK 1 & Kala wewa & $\begin{array}{l}\text { BG11, BG11 } \mathrm{C} \\
\text { and MLA }\end{array}$ \\
\hline
\end{tabular}

b) Culture, harvesting and bioassay for Artemia salina: Artemia salina bioassay was performed in 96 - well polystyrene plates. The Artemia cysts were incubated in $500 \mathrm{~mL}$ of artificial seawater for $48 \mathrm{~h}$. Cysts were illuminated with a tungsten filament light and maintained at room temperature $\left(27^{\circ} \mathrm{C}\right)$, with continuous aeration. Ten individuals of $A$. salina nauplii were placed in each well of the polystyrene plate and the extracted toxins were added to each well with artificial seawater medium to get a concentration series in duplicates. A control was also performed with artificial seawater. The plates were incubated at room temperature for $24 \mathrm{~h}$ (Meyer et al., 1982). After incubation, dead larvae in each well (or those swimming in a fixed position) were counted using a hand lens and the percentage mortality was calculated using the mean of two replicates. Results were expressed as percentage of mortality using the following formula and $\mathrm{LD}_{50}$ value was analysed with StatPlus 2009 Probit Analysis software.

$\%$ of mortality $=$ Number of dead shrimps in well after $24 \mathrm{~h} \times 100$

Number of shrimps initially placed in well
$\%$ of final mortality $=\%$ of mortality $-\%$ of mortality in control

\section{RESULTS AND DISCUSSION}

\section{Site selection and sample collection}

This study was performed to determine the presence of cyanotoxins in three main reservoirs (Kala wewa, Tissa wewa and Nuwara wewa) in the Anuradhapura District. These reservoirs are often used for drinking, recreational purposes, bathing, fishing and various other water related activities. Furthermore, they are the main water sources for irrigation. According to the data, mean temperatures of $27{ }^{\circ} \mathrm{C}, 28{ }^{\circ} \mathrm{C}$ and $27^{\circ} \mathrm{C}$ and mean $\mathrm{pH}$ of $8.5,8.34$ and 8.7 were observed in Nuwara wewa, Tissa wewa and Kala wewa, respectively (Table 1). Under microscope, Cylindrospermopsis species were recorded as the dominant cyanobacterial species in the environmental water samples collected from all three reservoirs along with M. aeruginosa, Anabaena spp., Chroococcus spp., Phormidium spp., Microcystis spp., Oscillatoria spp., Limnothrix spp., Lyngbia spp., Calothrix spp., Anabaenopsis spp., and Merismopedia spp., which were comparatively moderate to low in numbers. However, in culture samples in BG11, BG11 and $\mathrm{BG} 11_{0} \mathrm{C}$, no Cylindrospermopsis species were observed except Phormidium spp., Microcystis spp., Limnothrix spp., Lyngbia spp., and Merismopedia spp., Moreover, in the cultures in MLA medium, which lacks the inorganic nitrogen, Cylindrospermopsis was observed only in Nuwara wewa sample and also were biased to other filamentous forms with a minority of Merismopedia. Although Cylindrospermopsis is a filamentous heterocyst former, the reason for this contrast can be due to the culture media used for culturing (BG11, BG11 and BG11 ${ }_{0} \mathrm{C}$ ), which did not facilitate the growth of Cylindrospermopsis species. Further, it is well known that most of the microorganisms are non cultivable (Dadheech et al., 2009).

\section{Molecular detection}

The method employed for genomic DNA extraction resulted in high quality DNA in satisfactory amounts for amplification. According to the study done by Boutte et al. (2005), the primers, which are cyanobacterial specific CYA781 $\mathrm{Ra}$ and CYA781 Rb were used separately to identify heterocyst forming filamentous and unicellular non heterocyst forming filamentous cyanobacteria, respectively and equimolar mixture of CYA781Ra + CYA781Rb to identify the presence of cyanobacterial community in those reservoirs. According to the gel profiles obtained, all DNA samples 
submitted to PCR reactions with cyanobacterial specific oligonucleotide primers of CYA359F forward and CYA781Rb reverse primer yielded the unique fragment of $\sim 450$ bp (Table 3 and Figure 1a), indicating the presence of unicellular cyanobacteria in those reservoirs. However, the use of the forward primer CYA359F and the reverse primer CYA781Ra yielded $\sim 450$ bp fragment only in AN 8 from the environmental sample of the Nuwara wewa (Table 3) and AKI-C, AN7-C, AT5-C, and AT6-C samples, which were cultured in MLA medium (Table 3 and Figure 1b). These observations along with microscopic observations confirmed the presence of filamentous forms, which could be either heterocyst formers or non-heterocyst formers. Furthermore, all the samples yielded the $\sim 450$ bp unique fragment with CYA $359 \mathrm{~F}$ and the equimolar mixture of CYA781Ra + CYA $781 \mathrm{Rb}$ with different intensities (Table 3 and Figure $1 \mathrm{~b}$ ) signifying the presence of unicellular and filamentous cyanobacteria in those water bodies. The reason for these different intensities might be due to the competition of reverse primers to the same template, resulting in less complete genetic fingerprints (Boutte et al., 2005). In addition, positive amplification of $500 \mathrm{bp}$ in all the samples with cpc_arF and cpc_arR primers except AK3-C and AT5-C representing the presence of phycocyanin gene confirmed the presence of cyanobacteria (Table 3 and Figure 2).

AN8 and AT5 environmental samples gave positive amplification for the mcyA gene, yielding the unique

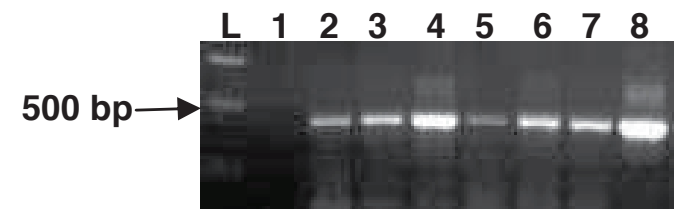

Figure 1a: Agarose gel profile (1.5\%) obtained for DNA samples amplified with CYA359F and CYA781Rb primers. Lane L- $1 \mathrm{~kb}$ DNA marker, lane 1- negative control (water), lane 2 - positive control (M. aureginosa), lanes 3-8 - AK1, AK3 AN6, AN7, AT5 and AT6 environmental samples.

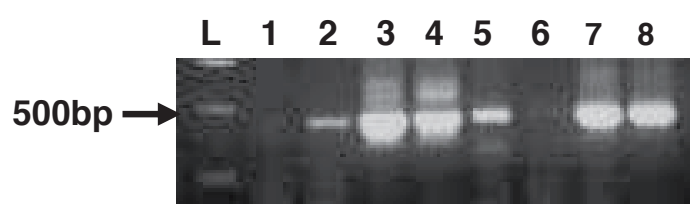

Figure 1b: Agarose gel profile (1.5\%) obtained for DNA samples amplified with CYA359F and CYA781 reverse primers. Lane L- $1 \mathrm{~kb}$ DNA marker, lane 1- negative control (water), lane 2 - positive control (M. aureginosa), lanes 3 and 4- AKI-MLA and AN7-MLA amplified with CYA781Rb, lanes 5 and 6- AKI-MLA and AN7-MLA amplified with CYA781Ra, lanes 7 and 8- AKI-MLA and AN7-MLA amplified with CYA781Ra+Rb.

Table 3: PCR amplification results

\begin{tabular}{|c|c|c|c|c|c|c|c|c|c|}
\hline \multirow{3}{*}{$\begin{array}{c}\text { Sample } \\
\text { no. }\end{array}$} & \multirow{3}{*}{$\begin{array}{l}\text { Sample } \\
\text { code }\end{array}$} & \multicolumn{8}{|c|}{ PCR amplification } \\
\hline & & \multicolumn{3}{|c|}{ CYA359F with } & \multirow[t]{2}{*}{$c p c$} & \multirow[t]{2}{*}{ McyA } & \multirow[t]{2}{*}{$M c y \mathrm{E}$} & \multirow[t]{2}{*}{ rpoC1 } & \multirow[t]{2}{*}{ M13/M14 } \\
\hline & & $\mathrm{Ra}$ & $\mathrm{Rb}$ & $\mathrm{Ra}+\mathrm{Rb}$ & & & & & \\
\hline 1 & AN 6 & -ve & $+\mathrm{ve}$ & $+\mathrm{ve}$ & $+\mathrm{ve}$ & -ve & $+\mathrm{ve}$ & -ve & -ve \\
\hline 2 & AN 7 & -ve & $+\mathrm{ve}$ & $+\mathrm{ve}$ & $+\mathrm{ve}$ & -ve & $+\mathrm{ve}$ & -ve & -ve \\
\hline 3 & AN8 & $+\mathrm{ve}$ & $+\mathrm{ve}$ & $+\mathrm{ve}$ & $+\mathrm{ve}$ & $+\mathrm{ve}$ & $+\mathrm{ve}$ & -ve & $+\mathrm{ve}$ \\
\hline 4 & AN6- C & -ve & $+\mathrm{ve}$ & $+\mathrm{ve}$ & $+\mathrm{ve}$ & -ve & $+\mathrm{ve}$ & -ve & -ve \\
\hline 5 & AN7-C & $+\mathrm{ve}$ & $+\mathrm{ve}$ & $+\mathrm{ve}$ & $+\mathrm{ve}$ & -ve & $+\mathrm{ve}$ & $+\mathrm{ve}$ & $+\mathrm{ve}$ \\
\hline 6 & AT 5 & -ve & $+\mathrm{ve}$ & $+\mathrm{ve}$ & $+\mathrm{ve}$ & $+\mathrm{ve}$ & $+\mathrm{ve}$ & -ve & -ve \\
\hline 7 & AT6 & -ve & $+\mathrm{ve}$ & $+\mathrm{ve}$ & $+\mathrm{ve}$ & -ve & $+\mathrm{ve}$ & -ve & -ve \\
\hline 8 & AT5- C & $+\mathrm{ve}$ & $+\mathrm{ve}$ & $+\mathrm{ve}$ & -ve & -ve & $+\mathrm{ve}$ & -ve & -ve \\
\hline 9 & AT6- C & $+\mathrm{ve}$ & $+\mathrm{ve}$ & $+\mathrm{ve}$ & $+\mathrm{ve}$ & -ve & $+\mathrm{ve}$ & -ve & $+\mathrm{ve}$ \\
\hline 10 & $\mathrm{AK} 1$ & -ve & $+\mathrm{ve}$ & $+\mathrm{ve}$ & $+\mathrm{ve}$ & -ve & -ve & -ve & -ve \\
\hline 11 & AK 3 & -ve & $+\mathrm{ve}$ & $+\mathrm{ve}$ & $+\mathrm{ve}$ & -ve & $+\mathrm{ve}$ & -ve & -ve \\
\hline 12 & AK1-C & $+\mathrm{ve}$ & $+\mathrm{ve}$ & $+\mathrm{ve}$ & $+\mathrm{ve}$ & -ve & $+\mathrm{ve}$ & -ve & $+\mathrm{ve}$ \\
\hline 13 & AK3-C & -ve & $+\mathrm{ve}$ & $+\mathrm{ve}$ & -ve & -ve & -ve & -ve & -ve \\
\hline
\end{tabular}

$+\mathrm{ve}=$ Positive amplification $\quad-\mathrm{ve}=$ Negative amplification 


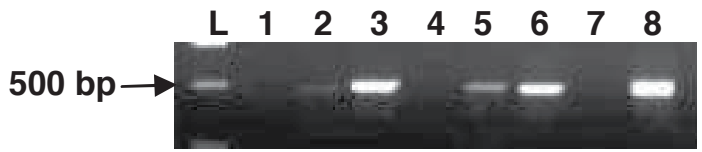

Figure 2: Agarose gel profile (1.5\%) obtained for DNA samples amplified with $\mathrm{Cpc} F$ and Cpc R primers. Lane L- $1 \mathrm{~kb}$ DNA marker, lane 1- negative control (water), lane 2 positive control (M. aureginosa), lanes 3-8 - AK1, AK3 AN6, AN7, AT5 and AT6 environmental samples.

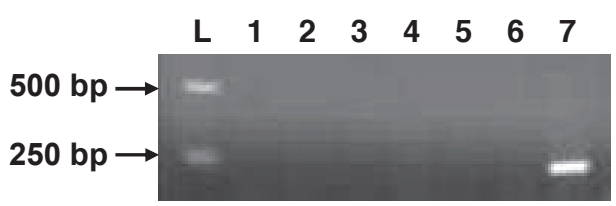

Figure 4: Agarose gel profile (1.5\%) obtained for DNA samples amplified with rpoC1-1 forward and rpoC1-T primer pair. Lane L- 1 kb DNA marker, lanes 1-7 AK1, AK1-MLA, AK3, AT5, AT6, AN7, AN7-MLA.

fragment of $594 \mathrm{bp}$, using the microcystin synthetase gene A forward primer (McyAR47) and genus specific reverse primer for Microcystis (McyAF19) (Table 3). This indicates the presence of cyanobacterial strains that have the genetic potential to produce microcystins. Further, all the samples gave positive amplification for the $m c y \mathrm{E}$ gene, yielding the unique $\sim 250 \mathrm{bp}$ except AK1 environmental sample and AK3-C, which was cultured in MLA medium (Table 3 and Figure 3). This indicates the presence of Microcystis strains in all three reservoirs that have the genetic potential to produce microcystins.

Only AN7-C DNA sample, which was cultured in MLA medium gave positive amplification with rpoC1 -1 forward and rpoC1 - T reverse primer, confirming the presence of cylindrospermopsin synthetase gene and therefore, the presence of Cylindrospermopsis species. Although the expected size was $609 \mathrm{bp}$ for the Cylindrospermopsis raciborskii, the only amplified product size was $\sim 250$ bp (Table 3 and Figure 4). The microscopic identification of the samples indicated the presence of Cylindrospermopsis species, and therefore, the resulting PCR product might be due to the presence of Cylindrospermopsis species other than

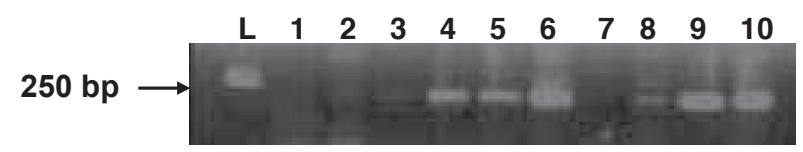

Figure 3: Agarose gel profile (1.5\%) obtained for DNA samples amplified with mcyE-F2 and MicmcyER8 primer pair. lane L- $1 \mathrm{~kb}$ DNA marker, lane 1- negative control (water), lane 2- positive control, lanes 3-6- AK1,AK3, AT5 and AN8 environmental samples respectively, lanes 7-10- AK3, AT6, AN6 and AN7 cultured in MLA medium, respectively.

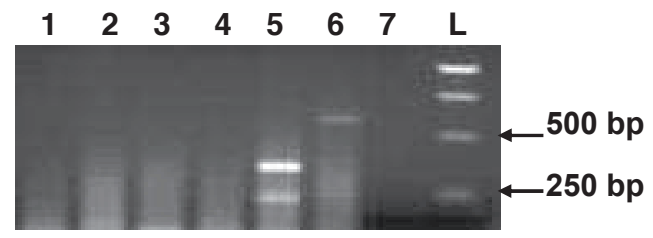

Figure 5: Agarose gel profile (1.5\%) obtained for DNA samples amplified with M13 and M14 primer pair. Lane L- 1kb DNA marker, lanes 1-7 AK1, AK3, AN6, AN7, AT5, AT6 and AN8 cultured in MLA medium.

Cylindrospermopsis raciborskii. A specific $\sim 597$ bp amplification was observed in AN8 environmental DNA sample with M13 forward and M14 reverse primers, while a $\sim 300$ bp unspecific amplification was observed in AK1-C, AN7-C and AT6-C DNA samples, which were cultured in MLA medium (Table 3 and Figure 5), indicating the presence of cylindrospermopsin specific peptide synthase (PS) gene and therefore, confirmed the presence of toxin producing Cylindrospermopsis species and also cylindrospermopsin. However, unspecific amplifications might be due to the other strains of Cylindrospermopsis, which also contain the peptide synthase (PS) gene.

\section{Bioassay detection}

The bioassay detection is based on the lethal effect of cyanotoxins on the brine shrimp, A. salina. This bioassay provides a viable tool since it is a representative species of the zooplankton community. According to the results obtained for bioassay, higher toxicity for A. salina after 24 hours was recorded in the filters compared to the filtrates (Table 4 and 5). Moreover, $50 \%$ of environmental samples showed higher toxicity compared to the cultured samples. 
Among the filtrates, the highest mortality of $66 \%$ was recorded in AK1 filtrate, which was cultured in MLA medium. A considerable amount of mortality (60\%) was also recorded in AK1 sample cultured in BG11 $\mathrm{C}$ (Table 4). Further, in filter samples, a sigmoid dose

Table 4: Percentage mortality of Artemia salina in the filtrate samples

\begin{tabular}{clcc}
\hline Sample No. & Sample code & $\begin{array}{c}\text { Total mortality } \\
\text { after } 24 \mathrm{~h}\end{array}$ & $\begin{array}{c}\% \text { of final } \\
\text { mortality }\end{array}$ \\
\hline 1 & Control & 0 & 0 \\
2 & AK1 & 0.3 & 3 \\
3 & AK3 & 0.3 & 3 \\
4 & AN1 & 0 & 0 \\
5 & AN6 & 0 & 0 \\
6 & AN7 & 0.3 & 3 \\
7 & AN8 & 1.3 & 13 \\
8 & AT5 & 0 & 0 \\
9 & AK1-BG11 ${ }_{0}$ C & 6 & 60 \\
10 & AK1-BG11 & 0 & 0 \\
11 & AK1-MLA & 6.6 & 66 \\
12 & AN1-BG11 & 0 & 0 \\
13 & AN1-BG11 & 0 \\
14 & AN6-BG11 & 0 & 0 \\
15 & AN7-BG11 ${ }_{0} \mathrm{C}$ & 0 & 0 \\
16 & AN7 - MLA & 0 & 0 \\
17 & AT5-BG11 & 0 & 0 \\
18 & AT3-BG11 & 0 & 0 \\
\hline
\end{tabular}

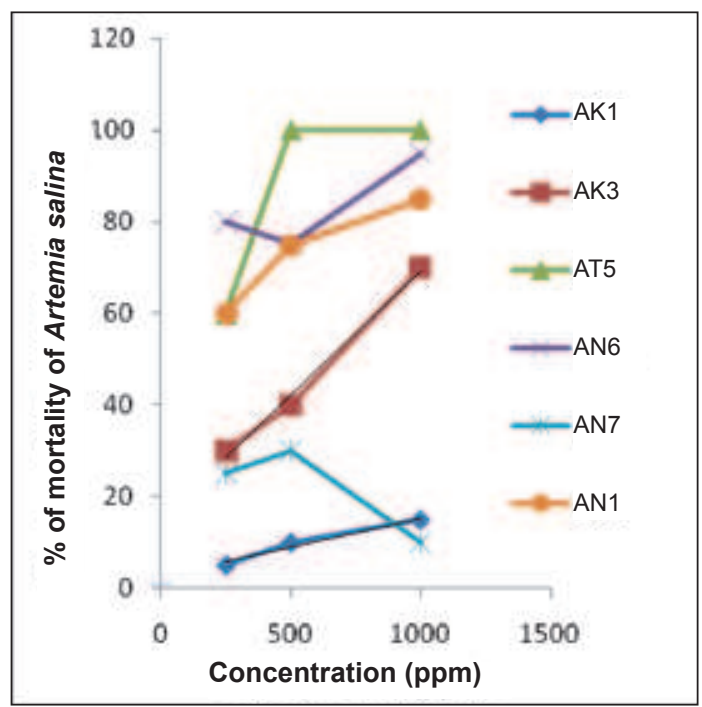

Figure 6: Percentage mortality of Artemia salina in different filters of environmental samples collected from Nuwara wewa (AN), Kala wewa (AK) and Tissa wewa (AT) response curve was obtained for all the samples with percentage of mortality increasing with the concentration of toxins (Figures 6 and 7), except AN6 and AN7 environmental samples and AK1 and AT5, which were cultured in BG11 medium (Table 5). However, for the 2 samples AT5 and AK1 cultured in BG11 medium, the mortality was independent from the concentration (Table 5). Among cultured samples in BG11 and BG11 ${ }_{0} \mathrm{C}$ media, the highest toxicity was recorded in the Nuwara wewa samples.

According to the $\mathrm{LD}_{50}$ values obtained for filter samples, the highest toxicity was recorded in AN6 ( $\mathrm{LD}_{50}$ : - 694 ppm) and AN7 (LD : - 694 ppm) (Table 6), environmental samples collected from Nuwara wewa. Among cultured samples, the highest toxicity was recorded in AK1 ( $\left.\mathrm{LD}_{50}:-1128.28 \mathrm{ppm}\right)$ sample, which was cultured in BG11 ${ }_{0} \mathrm{C}$ medium (Table 6).

Beside chemical analyses of cyanobacterial toxins, a wide range of biological laboratory methods have been developed for detection and identification of the cyanotoxins in cyanobacterial biomass and raw waters. Since analytical analysis cannot describe the real toxic effect of complex mixtures of chemicals, relatively simple and low cost methods provide necessary additional information on overall toxicity, and allow rapid evaluation of the potential hazard for humans, animals or ecosystems. A specific biological screening method can be selected, depending on the type of information required. However,

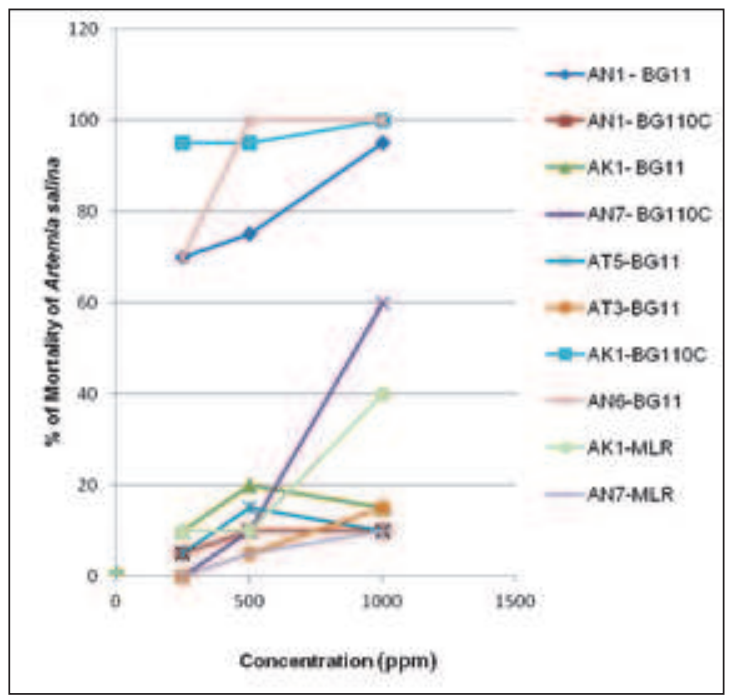

Figure 7: Percentage mortality of Artemia salina in different filters for cultured isolates originated from cyano specific culture media for water samples collected from Nuwara wewa (AN), Kala wewa (AK) and Tissa wewa (AT) 
Table 5: Percentage mortality of Artemia salina in the filter samples

\begin{tabular}{|c|c|c|c|c|}
\hline Sample No. & Sample code & Toxin concentration-ppm & Total mortility after 24 hours & $\%$ of final mortility \\
\hline 1 & Control & 0 & 0 & 0 \\
\hline 2 & AK1 & 1000 & 1.5 & 15 \\
\hline 3 & AK1 & 500 & 1 & 10 \\
\hline 4 & AK1 & 250 & 0.5 & 5 \\
\hline 5 & AK3 & 1000 & 7 & 70 \\
\hline 6 & AK3 & 500 & 4 & 40 \\
\hline 7 & AK3 & 250 & 3 & 30 \\
\hline 8 & AT5 & 1000 & 10 & 100 \\
\hline 9 & AT5 & 500 & 10 & 100 \\
\hline 10 & AT5 & 250 & 6 & 60 \\
\hline 11 & AN6 & 1000 & 9.5 & 95 \\
\hline 12 & AN6 & 500 & 7.5 & 75 \\
\hline 13 & AN6 & 250 & 8 & 80 \\
\hline 14 & AN7 & 1000 & 1 & 10 \\
\hline 15 & AN7 & 500 & 3 & 30 \\
\hline 16 & AN7 & 250 & 2.5 & 25 \\
\hline 17 & AN1 & 1000 & 8.5 & 85 \\
\hline 18 & AN1 & 500 & 7.5 & 75 \\
\hline 19 & AN1 & 250 & 6 & 60 \\
\hline 20 & AN1- BG11 & 1000 & 9.5 & 95 \\
\hline 21 & AN1- BG11 & 500 & 7.5 & 75 \\
\hline 22 & AN1-BG11 & 250 & 7 & 70 \\
\hline 23 & $\mathrm{AN} 1-\mathrm{BG} 11_{0} \mathrm{C}$ & 1000 & 1 & 10 \\
\hline 24 & $\mathrm{AN} 1-\mathrm{BG} 11_{0} \mathrm{C}$ & 500 & 1 & 10 \\
\hline 25 & $\mathrm{AN} 1-\mathrm{BG} 11_{0} \mathrm{C}$ & 250 & 0.5 & 5 \\
\hline 26 & AK1-BG11 & 1000 & 1.5 & 15 \\
\hline 27 & AK1-BG11 & 500 & 2 & 20 \\
\hline 28 & AK1-BG11 & 250 & 1 & 10 \\
\hline 29 & AN7-BG11 ${ }_{0} \mathrm{C}$ & 1000 & 6 & 60 \\
\hline 30 & AN7-BG11 ${ }_{0} \mathrm{C}$ & 500 & 1 & 10 \\
\hline 31 & $\mathrm{AN7}-\mathrm{BG} 11_{0} \mathrm{C}$ & 250 & 0 & 0 \\
\hline 32 & AT5-BG11 & 1000 & 1 & 10 \\
\hline 33 & AT5-BG11 & 500 & 1.5 & 15 \\
\hline 34 & AT5-BG11 & 250 & 0.5 & 5 \\
\hline 35 & AT3-BG11 & 1000 & 1.5 & 15 \\
\hline 36 & AT3-BG11 & 500 & 0.5 & 5 \\
\hline 37 & AT3-BG11 & 250 & 0 & 0 \\
\hline 38 & $\mathrm{AK} 1-\mathrm{BG} 11_{0} \mathrm{C}$ & 1000 & 10 & 100 \\
\hline 39 & $\mathrm{AK} 1-\mathrm{BG} 11_{0} \mathrm{C}$ & 500 & 9.5 & 95 \\
\hline 40 & $\mathrm{AK} 1-\mathrm{BG} 11_{0} \mathrm{C}$ & 250 & 9.5 & 95 \\
\hline 41 & AN6-BG11 & 1000 & 10 & 100 \\
\hline 42 & AN6-BG11 & 500 & 10 & 100 \\
\hline 43 & AN6-BG11 & 250 & 7 & 70 \\
\hline 44 & AK1 - MLA & 1000 & 4 & 40 \\
\hline 45 & AK1 - MLA & 500 & 1 & 10 \\
\hline 46 & AK1 - MLA & 250 & 1 & 10 \\
\hline 47 & AN7-MLA & 1000 & 1 & 10 \\
\hline 48 & AN7-MLA & 500 & 0.5 & 5 \\
\hline 49 & AN7-MLA & 250 & 0 & 0 \\
\hline
\end{tabular}


Table 6: $\quad \mathrm{LD}_{50}$ values for filter samples

\begin{tabular}{lr}
\hline Sample code & LD $_{50}(\mathrm{ppm})$ \\
\hline AK1 & $3,216.84$ \\
AK3 & 643.44 \\
AT5 & 96.95 \\
AN6 & -694.97 \\
AN7 & -694.97 \\
AN1 & -118.08 \\
AN1- BG11 & -157.49 \\
AN1 -BG11 & $3,216.84$ \\
AK1-BG11 & 1539.92 \\
AN7-BG11 ${ }_{0}$ r & 917.51 \\
AT5-BG11 & 3216.84 \\
AT3-BG11 & 2286.30 \\
AK1-BG11 C & -1128.28 \\
AN6-BG11 & -54.64 \\
AK1 - MLA & 1194.64 \\
AN7-MLA & 2286.30 \\
\hline
\end{tabular}

it is important to note that there cannot be one single method providing adequate information on toxicity of all types of cyanotoxins. Therefore, analysis of chemical composition in the algal extract is important to verify the toxicity. However, the most widely used invertebrate bioassay available for cyanotoxins is the brine shrimp (Artemia salina) assay (Kiviranta et al., 1991; Lawton et al., 1994). This is a useful toxicity screening method used in very basic laboratories as it requires little expertise and does not require culture maintenance or special equipment.

This research study focused on cyanotoxins, because most males (from childhood to adulthood) in the Dry Zone, often use lake water for recreational purposes, bathing and washing after farming, fishing and various water related activities. Recreational use of lakes, rivers and canals is the most common route of exposure to cyanobacterial toxins. As an example, in 1959 in Canada, 12 people became ill with headaches, nausea, muscular pains and acute gastroenteritis symptoms (Dillenberg \& Dehnel, 1959). The illness was noted in people who had been swimming in a lake contaminated by toxins from Anabaena, before the intoxication. In England in 1989, 10 of 20 soldiers became ill after swimming and canoetraining in water with a heavy bloom of Microcystis (Turner et al., 1990) and two cases of pneumonia were noted among the soldiers. According to Mehra et al. (2009), an additional aspect influencing the toxicity of cyanobacterial blooms is the age of the victim. Children are more vulnerable for several reasons: they drink more water per unit of body weight, are less likely to have a choice of the source of drinking water and are more susceptible to damage that takes a considerable time to develop, such as environmentally induced carcinomas. It is a common sight in the Dry Zone tanks, where lots of children, mainly boys spend hours in the water and therefore, the direct ingestion of cyanotoxic water by the swimmers for a long period, might be the cause for the mysterious chronic kidney disease, cancers and other human illnesses recorded in the Dry Zone.

Healthy people are less susceptible to cyanotoxicosis than people with hepatitis, alcoholism or kidney damage. Patients who undergo kidney dialysis are especially susceptible to toxic damage from cyanobacteria. In 1996 in Caruaru, Brazil, 131 dialysis patients were exposed to microcystins via water used for dialysis; 56 of them died and the others had typical symptoms of harm from microcystins such as nausea, vomiting and painful, excessive enlargement of the liver (Jochimsen et al., 1998). The episode of deaths of haemodialysis patients at the Caruaru dialysis clinic emphasized the importance of haemodialysis water as an exposure route for microcystins (Codd, 2000).

According to the investigations in all three reservoirs, Cylindrospermopsis species were recorded as the dominant cyanobacterial species along with a vast diversity of cyanobacterial species in moderate numbers. Except Chroococcus, the rest of the cyanobacterial species which have been recorded, has the genetic potential to generate toxins. Microcystins, which is a most common class of toxins worldwide, is mainly produced by $M$. aeruginosa and other species of Microcystis, and these were moderately present in all three lakes. The mechanisms of toxicity of the diverse cyanobacterial toxins include nerve ion-channel blocking, neuromuscular blockade, anti-acetyl cholinesterase activity, antiphosphatase activity and protein synthesis inhibition. The liver is particularly damaged by the latter two activities, as well as the gastro intestinal tract and, in the case of protein synthesis inhibition, the kidneys. The anti-phosphatase activity of microcystins and nodularin has significant potential for stimulating tumour growth. This capacity is clearly demonstrated experimentally, and its mechanism is under detailed investigation. Cyanobacterial poisons can affect not only hepatocytes but also other types of cells. Microcystins and nodularins can inhibit the activity of protein phosphatases PP1 and PP2A in any eukaryotic cell they can get into, but usually need the bile acid carrier to cross cell membranes. Apoptotic changes have been observed after microinjection of microcystins or nodularins into human embryo kidney HEK 293, Swiss 3T3 mouse embryo fibroblast, breast carcinoma cell line MCF-7 and rat promyelocytic IPC-81 leukemia cells 
(Fladmark et al., 1999). Morphological changes such as membrane budding, cell shrinkage and organelle redistribution have been seen in human fibroblasts, human endothelial cells, human epithelial cells, human lymphocytes and rat promyelocytes (Mcdermott et al., 1998; Mankiewicz et al., 2001). Microcystins also have a clastogenic effect in human lymphocytes, connected with a dose-related increase of chromosomal breakage (Repavich et al., 1990; Premazzi \& Volterra, 1993). According to a previous study, the cytotoxic alkaloid cylindrospermopsin produced by Cylindrospermopsis species, were the dominant species in three lakes and it generally blocks the protein synthesis (Hawkins et al., 1985). The first clinical symptoms of poisoning are kidney and liver failure; it also causes damage to the spleen, intestine, heart and thymus. Cylindrospermopsin is especially dangerous because clinical symptoms may become manifest only several days after exposure, so the toxic effects can be difficult to correlate. Tumor promotion by exposure to cyanobacterial toxins poses an added risk, and in some areas of the Dry Zone the number of deaths due to cancer has increased sharply within the last few years.

According to the findings of this study, all three lakes show a wide distribution of cyanobacterial species with toxin generating ability and it might be a major risk factor for various human illnesses recorded in the Dry Zone. Therefore, more epidemiological studies are required to explore the relationship existing between human illnesses and cyanotoxins in water.

In conclusion, molecular detection data and bioassays have confirmed the presence of toxic cyanobacteria in all three sampled water reservoirs. Further, molecular data confirmed the presence of cyanobacterial strains that have the genetic potential to produce microcystins and more importantly, the presence of Cylindrospermopsis and also the presence of cylindrospermopsin producing Cylindrospermopsis species. The bioassay results confirmed the presence of lethal cyanotoxins in collected water samples. However, there is a need for extensive studies to identify the types of cyanobacteria, cyanotoxins, their variants, compositions and the level of toxicity present in those water reservoirs to correlate it with the present issue of human illnesses.

\section{REFERENCES}

1. Boom R., Sol C.J., Salimans M.M., Jansen C.L., Wertheimvan Dillen P.M. \& van der Noordaa J. (1990). Rapid and simple method for purification of nucleic acids. Journal of Clinical Microbiology 28(3): 495 - 503.

2. Boutte C., Grubisic S., Balthasart P. \& Wilmotte A. (2005).
Testing of primers for the study of cyanobacterial molecular diversity by DGGE. Journal of Microbiological Methods 65(3): 542-550.

3. Byth S. (1980). Palm Island mystery disease. Medical Journal of Australia 2: $40-42$.

4. Codd G.A. (2000). Cyanobacterial toxin, the perception of water quality and the prioritization of eutrophication control. Ecological Engineering 16: 51-60.

5. Chorus I., Falconer I.R., Salas H.J. \& Bartram J. (2000). Health risks caused by freshwater cyanobacteria in recreational waters. Journal of Toxicology and Environmental Health, Part B 3(4): 323-347.

6. Dadheech P.K., Krienitz L., Kotut K., Ballot A. \& Casper P. (2009). Molecular detection of uncultured cyanobacteria and aminotransferase domains for cyanotoxin production in sediments of Kenyan lakes. FEMS Microbiology Ecology 68(3): $340-350$.

7. Dillenberg H.O. \& Dehnel M.K. (1959). Toxic water bloom in Saskatchewan. Canadian Medical Association Journal 83: $1151-1154$.

8. Falconer I.R. (1996). Potential impact on human health of toxic cyanobacteria. Phycologia 35: 6-11.

9. Falconer I.R. (2005). Cyanobacterial poisoning of livestock and people. Cyanobacterial Toxins of Drinking Water Supplies: Cylindrospermopsins and Microcystins. CRC Press, Boca Raton, FIorida, USA.

10. Falconer I.R., Beresford A.M. \& Runnegar M.T. (1983). Evidence of liver damage by toxin from a bloom of the blue- green alga, Microcystis aeruginosa. Medical Journal of Australia 1:511-514.

11. Fastner J., Flieger I. \& Neumann U. (1998). Optimized extraction of microcystins from field samples - a comparison of different solvents and procedures. Water Research 32: $3177-3181$.

12. Fladmark K.E., Brustugun O.T., Hovald R., Boe R., Gjertsen B.T., Zhivotovsky B. \& Doskeland S.O. (1999). Ultrarapid scapase-3 dependent apoptosis induction by serine/threonine phosphatase inhibitors. Cell Death and Differentiation 6: $1099-1108$.

13. Hawkins P.R., Runnegar M.T., Jackson A.R. \& Falconer I.R. (1985). Severe hepatotoxicity caused by the tropical cyanobacterium (blue-green algae) Cylindrospermopsis raciborskii (Woloszynska) Seenaya and Subba Raju isolated from a domestic water supply reservoir. Applied and Environmental Microbiology 50: 1292-1295.

14. Jochimsen E.M., Carmichael W.W., An J.S., Cardo D.M., Cookson S.T., Holmes C.E., Antunes M.B., de Melo Filho D.A., Lyra T.M., Barreto V.S., Azevedo S.M. \& Jarvis W.R. (1998). Liver failure and death after exposure to microcystins at a hemodialysis center in Brazil. New England Journal of Medicine 338: 873 - 878.

15. Kiviranta J., Sivonen K., Niemelä S.I. \& Huovinen K. (1991). Detection of toxicity of cyanobacteria by Artemia salina bioassay. Environmental Toxicology and Water Quality 6: 423-426.

16. Kuiper-Goodman T., Falconer I.R. \& Fitzgerald D.J. (1999). Human health aspects. Toxic cyanobacteria in water: A guide to their public health consequences, monitoring and management (eds. I. Chorus \& J. Bartram), pp. 114-153. E 
\& FN Spon Publishers, London, UK.

17. Lawton L.A., Edwards C. \& Codd G.A. (1994). Extraction and high performance liquid chromatographic method for the determination of microcystins in raw and treated waters. Analyst 119: 1525-1530.

18. Mankiewicz J., Tarczynska M., Fladmark K.E., Doskeland S.O., Walter Z. \& Zalewski M. (2001). Apoptotic effect of cyanobacterial extract on rat hepatocytes and human lymphocytes. Environmental Toxicology 16(3): 225-233.

19. Mcdermott C.M., Nho C.W., Howard W. \& Holton B. (1998). The cyanobacterial toxin, microcystin-LR, can induce apoptosis in a variety of cell types. Toxicon 36: 1981-1996.

20. Mehra S., Dubey J. \& Bhowmik D. (2009). Impact of natural toxins from cyanobacterial blooms in eutrophic lakes. American-Eurasian Journal of Toxicological Sciences 1(2): 57-68.

21. Meyer B.N., Ferrigni N.R., Putnam J.E., Jacobsen L.B., Nicolas D.E. \& McLaughlin J.L. (1982). Brine shrimp: a convenient general bioassay for active plant constituents. Planta Medica 45: 31-34.

22. Nübel U., Garcia-Pichel F. \& Muyzer G. (1997). PCR primers to amplify 16S rRNA genes from cyanobacteria. Applied and Environmental Microbiology 63(8): 3327-3332.

23. Palenik B. \& Haselkorn R. (1992). Multiple evolutionary origins of pro-chlorophytes, the chlorophyll-containing prokaryotes. Nature 355: 265-267.

24. Premanandh J., Balakrishnan P., Teneva I., Dzhambazov B., Prabaharan D. \& Uma L. (2006). Molecular characterization of marine cyanobacteria from the Indian subcontinent deduced from sequence analysis of phycocyanin operon ( $c p c B-I G S-c p c A)$ and $16 \mathrm{~S}-23 \mathrm{~S}$ ITS region. The Journal of Microbiology 44: 607- 616.

25. Premazzi G. \& Volterra L. (1993). Microphyte Toxins. A Manual for Toxin Detection, Environmental Monitoring and Therapies to Counteract Intoxications. Joint Research
Centre, Commission of the European Communities, Luxembourg.

26. Repavich W.M., Sonzogni W.C., Standridge J.H., Wedepohl R.E. \& Meisner L.F. (1990). Cyanobacteria (blue-green algae) in Wisconsin water acute and chronic toxicity. Water Research 24: 225-231.

27. Roger P. A. \& Kulasooriya S. A. (1980). Ecology of blue green algae in paddy fields. Blue-Green Algae and Rice, pp. 10 -36. The International Rice Research Institute. Los Banos, Laguna, Philippines.

28. Schembri M.A., Neilan B.A. \& Saint C.P. (2001). Identification of genes implicated in toxin production in the cyanobacterium Cylindrospermopsis raciborskii. Environmental Toxicology 16: 413 - 421.

29. Sivonen K. \& Jones G. (1999). Cyanobacterial toxins. Toxic Cyanobacteria in Water: A Guide to Their Public Health Consequences, Monitoring, and Management, (eds. I. Chorus \& J. Bartram), pp. 41-111. E \& FN Spon Publishers, London, UK.

30. Sivonen K., Niemelä S.I., Niemi R.M., Lepistö L., Luoma T. H. \& Räsänen L. A. (1990). Toxic cyanobacteria (blue-green algae) in Finnish fresh and coastal waters. Hydrobiology 190: 267-275.

31. Turner P.C., Gammie A.J., Hollinrake K. \& Codd G.A. (1990.) Pneumonia associated with contact with cyanobacteria. British Medical Journal 300: 1440-1441.

32. Vaitomaa J., Rantala A., Halinen K., Rouhiainen L., Tallberg P., Mokelke L. \& Sivonen K. (2003). Quantitative real - time PCR for determination of Microcystin Synthetase E copy numbers for Microcystis and Anabaena in lakes. Applied and Environmental Microbiology 69(12): 7289-7297.

33. Wilson K.M., Schembri M.A., Baker P.D. \& Saint C.P. (2000). Molecular characterization of the toxic cyanobacterium Cylindrospermopsis raciborskii and design of a species-specific PCR. Applied and Environmental Microbiology 66(1): 333-338. 